\title{
Urban water sustainability for Yanbu Industrial City
}

\author{
E. M. Qaisaran \& A. A. Al-Qurashi \\ Engineering Dept., Technical Affairs Division, \\ Royal Commission at Yanbu, Royal Commission for Jubail and Yanbu, \\ Kingdom of Saudi Arabia
}

\begin{abstract}
Yanbu Industrial City (YIC) is known as a new, modern, and heavy industrial urbanization. For that reason the need for new urban water sustainability is probably more evident than in other cities. YIC has been a utility island, selfcontained and unconnected to any regional power or water systems.

Water sustainability has become a top policy discussion to maintain or enhance all natural and urban elements' growth without compromising the future. YIC where urban areas, their economies and industries are expected to grow rapidly over the next few decades and where natural resource use and environmental quality are already raising grave concerns. Fortunately, Royal Commission Leaders have responded to the challenge by making urban water sustainability development a high priority.

The Royal Commission at Yanbu has addressed and overcome many challenges to balance the never ending water sustainability by implementing the integration of all aspects of infrastructure work including: water desalination and distribution, seawater cooling, wastewater treatment industrial sewer), reclaimed water network (fire fighting), sanitary wastewater treatment, irrigation water network and environmental monitoring programs which include ambient monitoring which helps to ensure industries' compliance with environmental regulations and standards, and provides baseline data for use in trend predictions and planning strategies. In addition to ambient monitoring which covers meteorology; air, ground-water, seawater quality; marine and terrestrial ecosystems.

YIC's goal of urban water sustainability is to "meet the needs of the present without compromising the ability of future generations to meet their own needs."
\end{abstract}


As key forces in all kinds of modern civilization aspects have an important role to play in achieving this goal.

Keywords: urban planning process, desalinated water, utilities, seawater cooling, conservation, treatment systems.

\section{Introduction}

On September 21, 1975, the late King Khaled issued a royal decree establishing the Royal Commission for Jubail and Yanbu. Yanbu Industrial City (Yanbu 1) is a planned industrial community located on Saudi Arabia's Red Sea coast approximately 350 kilometers north of Jeddah [2] (Figure 1). In existence for little more than three decades, Yanbu is currently host to 14 major industrial facilities - two refineries, a petrochemical complex, a natural gas liquid fractionation plant, and a crude oil export terminal, 19 secondary, and 52 support, and light manufacturing enterprises. More industrial facilities are currently under construction or in various stages in design and planning [3].

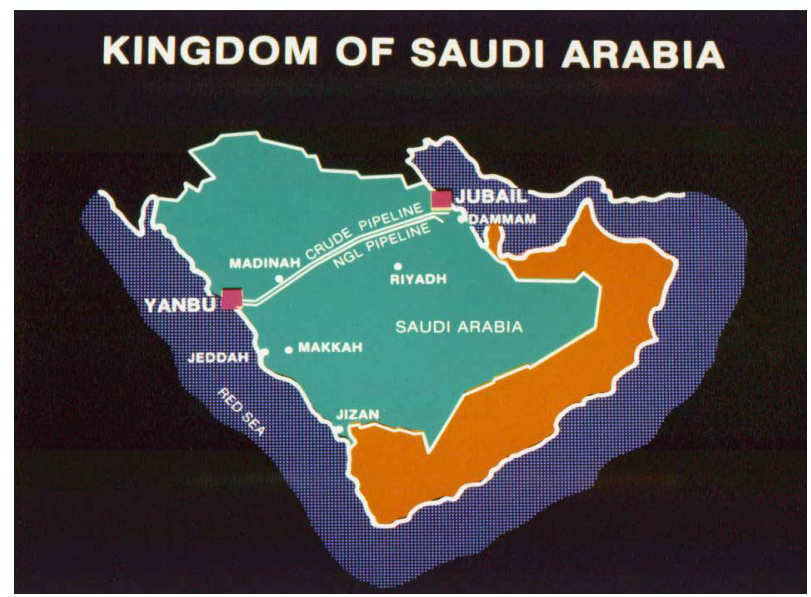

Figure 1: $\quad$ Yanbu location map.

Yanbu Industrial City (Yanbu 1) occupies a 24-kilometer-long coastal site 19 kilometers southeast of the historic community of Yanbu AI-Bahr. The project site encompasses 185 square kilometers, two-thirds of which is dedicated to industrial development. At the northern end of the site upwind of the industrial area and separated from it by a buffer zone is the permanent residential community [2].

\section{The YIC urban planning process}

The program to prepare the Master Plan 2000 ensured that national goals and objectives formed the basis of the plan, and that input at the regional level 
established a broad physical, economic and social structure within which to frame the development options for the city. In addition, a Vision Workshop helped give direction for the overall growth of the city [1].

As a component of the Master Plan, a growth rate has been used which forecasts how much land will be needed in the industrial area and the community area over time. Based on the anticipated growth rate, "build-out" of the community area will occur around 2030.

The Master Plan also outlined several key implementation measures that are critical to its success. The zoning and subdivision regulations together with a Community Development Manual have been used as a form of Urban Design Guidelines to supplement the existing zoning regulations. With preparation of the new Master Plan, plans are underway to update existing implementation measures. The city has also taken the initiative to implement additional programs including Urban Design Guidelines, Development of the Waterfront, the 10 Year Action Plan, City Center Development and Specific Area Plan.

These accomplishments were made in a manner that balances industrial development and environmental conservation. From the outset, the city made a conscious decision, even before construction work began, to perform its assigned task in a way that would be beneficial to both man and nature. It conducted environmental impact studies, formulated strict regulations limiting airborne pollutants and effluent discharge and established a vast monitoring system

In the 30 years since its establishment, YIC has accomplished what some had considered impossible. It has helped build a thriving city that is considered a model of industrial and community development. Today, the city employs and trains thousands of Saudis, produces billions of dollars' worth of quality products for domestic and international markets, and contributes to the Kingdom's prosperity and overall growth (Figures 2 and 3).

\section{YIC's water utilities}

YIC produces its own power and fresh water in a single integrated plant located in the city's primary industry park. This facility can generate up to $840 \mathrm{MW}$ of power and 74,000 cubic meters of desalinated water per day. The Royal Commission oversees utility distribution and has installed 440 kilometers of 115$\mathrm{kv}$ power cable and some 600 kilometers of potable water lines [1].

\subsection{Desalinated water}

Potable water production has steadily increased over the last twenty years from approximately 20 to 40 thousand cubic meters per day; that is, an overall increase of 100 percent, corresponding to a 10 percent yearly increase.

The major consumer of potable water is the residential community, which accounts for approximately $92.5 \%$ of total consumption, whereas all industries account for $7.5 \%$. The daily consumption per resident population amounts to approximately 700 liters per day. This rate includes commercial and industrial 


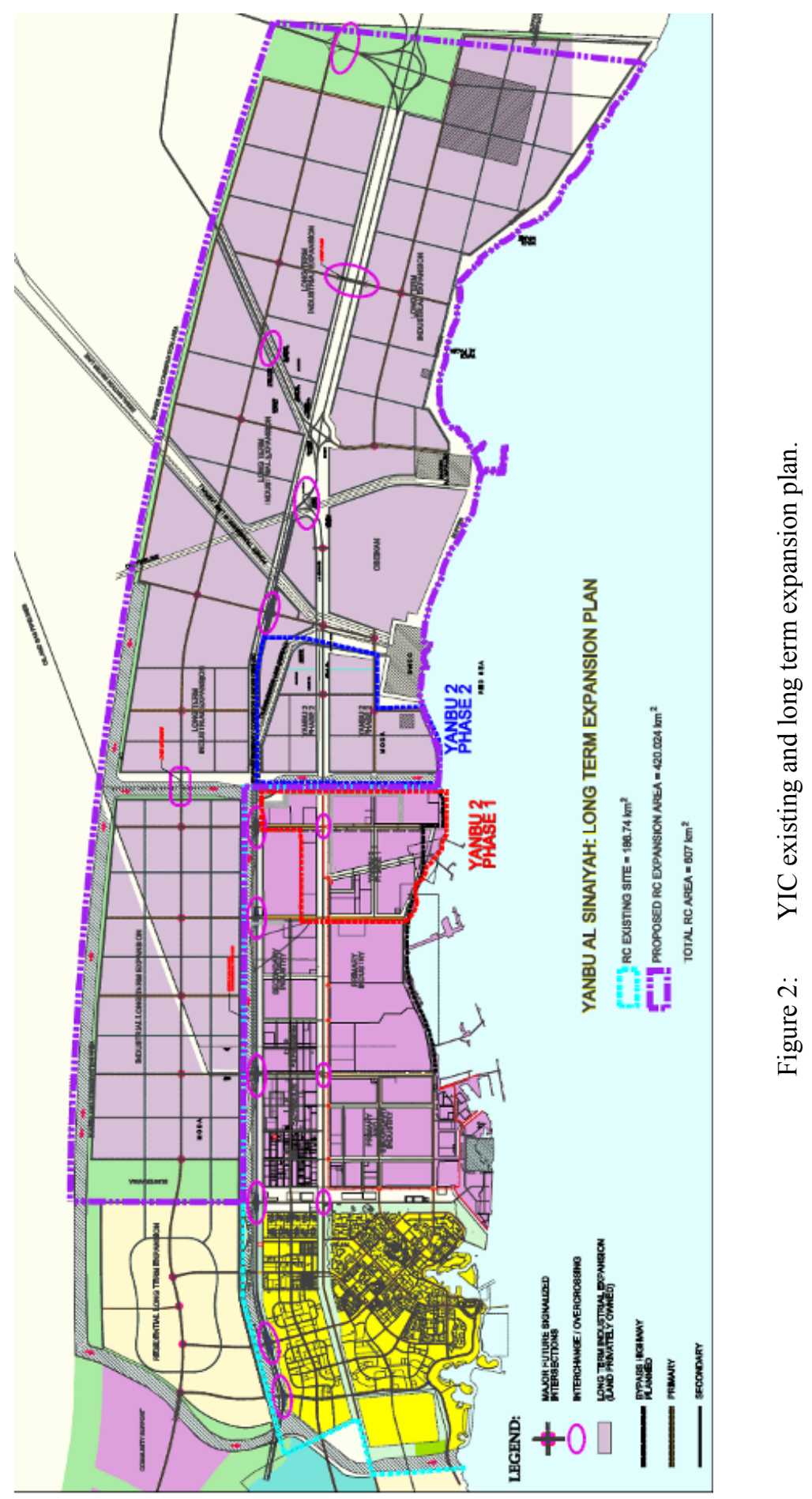



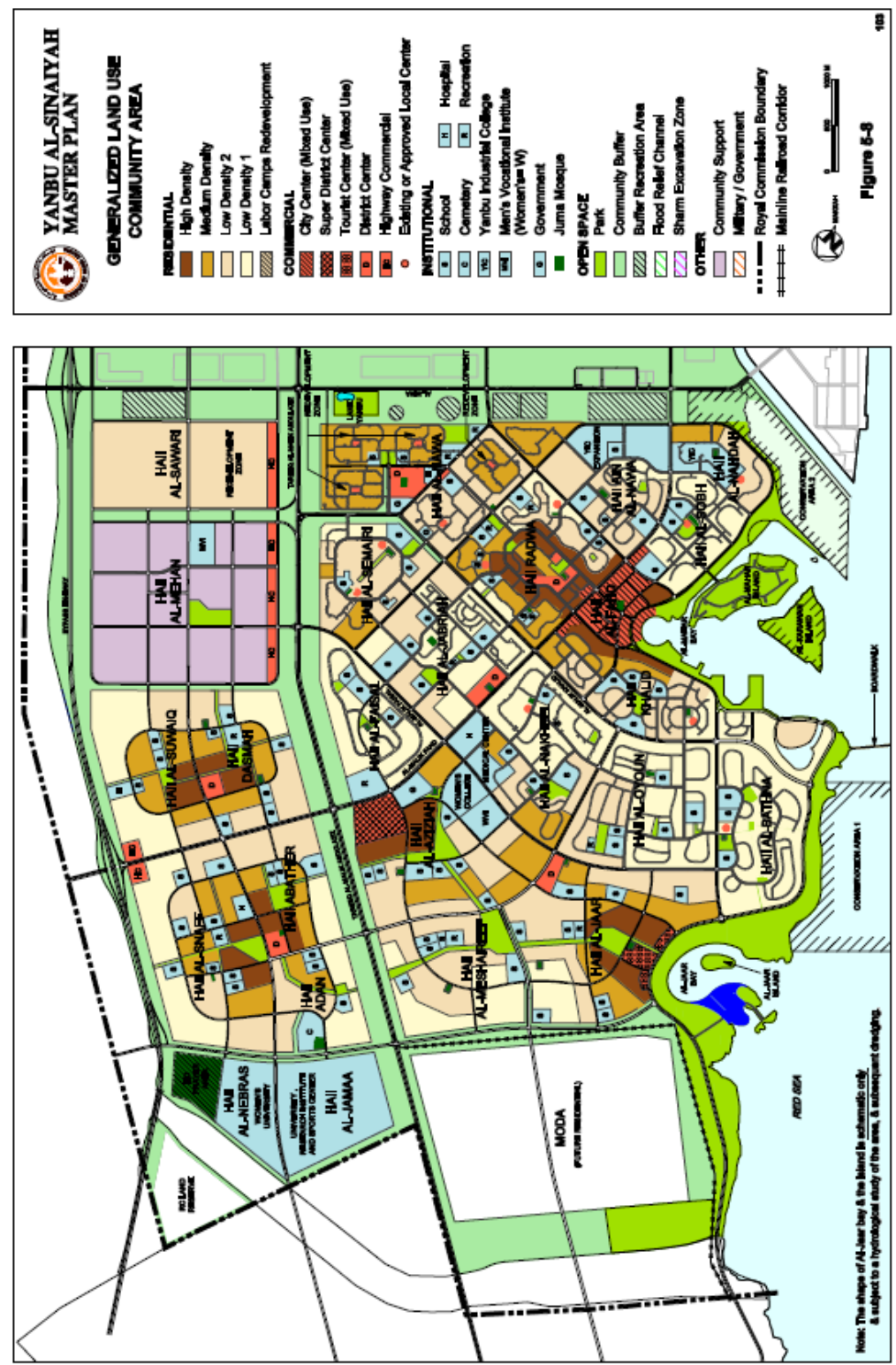

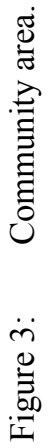




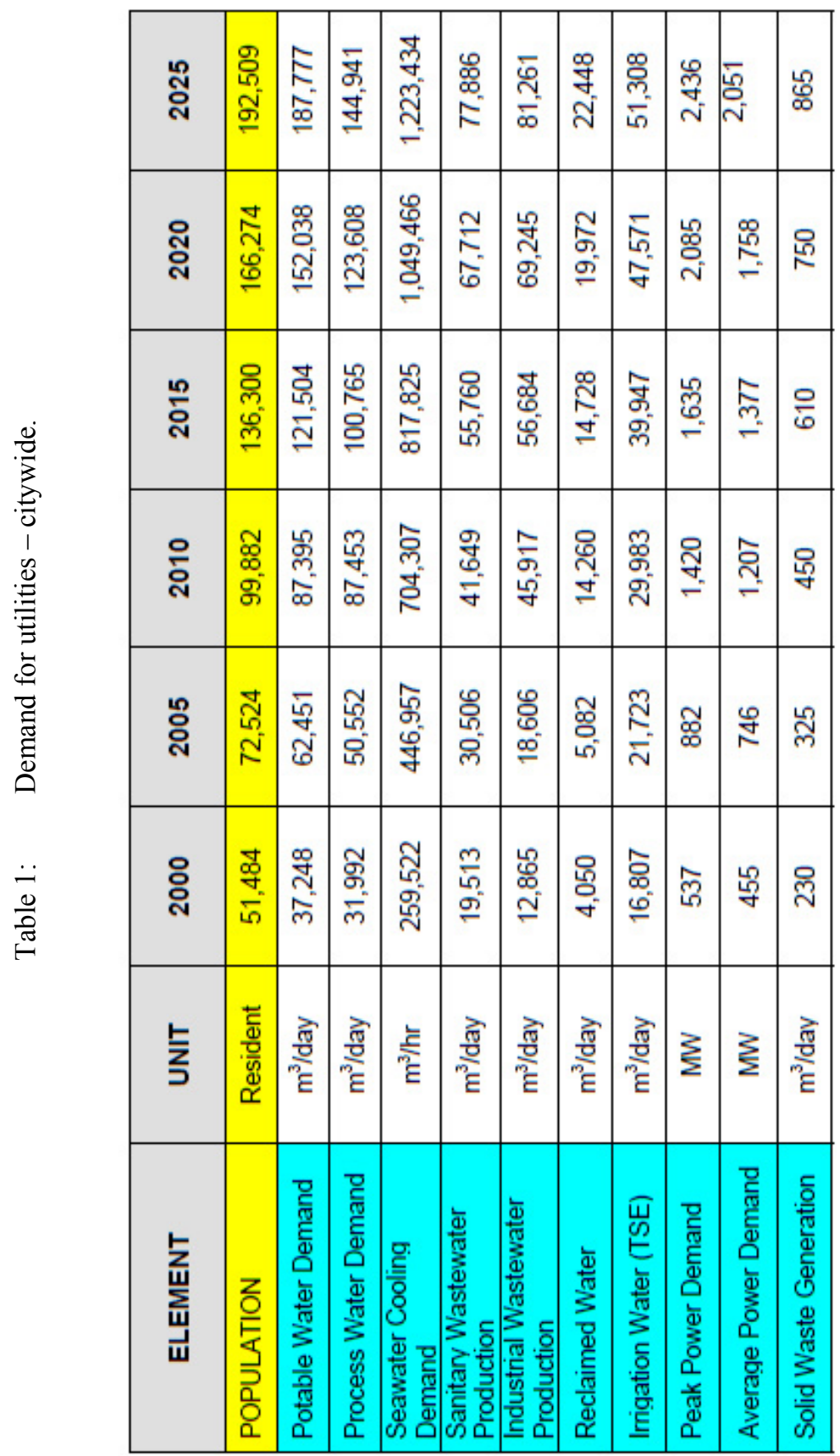


uses, landscaping and irrigation. At build out, potable water demand is expected to exceed $150,000 \mathrm{~m}^{3} /$ day. This is three to four times the current demand.

The Original Master Plan called for potable water storage capacity of seven (7) days for normal use including one (1) day for fire fighting. This requirement is based on the average demand. Currently this requirement cannot be met without additional storage capacity. YIC has recently adopted a policy for potable and process water storage capacity which found that the most practical storage capacity periods are 7 days for potable water and 5 days for process water.

- The projected demand for desalinated water from the industries and community demand is shown in (Figure 3 ).

- Water loss in the system is minimal, and amounts to less than $1 \%$. This is an excellent rate, and one of the best in the world (Typical water loss rates are $15-30 \%)$.

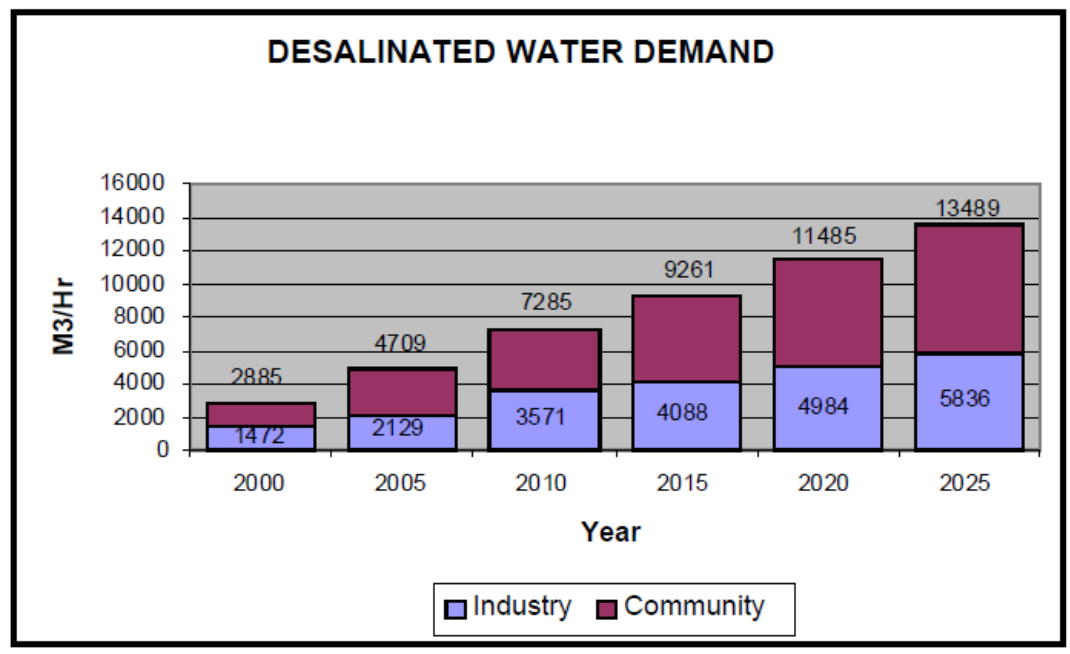

Figure 3: Desalinated water demand.

\subsubsection{Integrated water resources program}

Update the existing Water Master Plan within an Integrated Water Resources Program for the city, using the Master Plan Land Use Plan as the basis. Such a plan should address the following recommendations and policies: Revision of basic design criteria and Standards. Future water demand. Water sources. Main piping network (transmissions lines, distribution loops, etc.) and pumping station. Possibility of using gravity pressure for expansion zones. Feasibility of individual water reservoirs for large buildings to alleviate reliance on water pressure provided at the pumping stations (example: ground reservoir complemented by a reservoir on top of building). Water conservation program: Upgrade water sources (water production will be needed to accommodate future growth, additional desalination units may be required). Transmission lines, 
pumping stations and distribution networks to accommodate planned development. Metering, public awareness campaign, pricing, maintenance of distribution system to minimize losses/leakage, etc.

New water sources: use reclaimed water (treated industrial wastewater) in addition to the use of treated sanitary wastewater (or treated sewage effluent, TSE). Examine the feasibility of creating water pressure zones throughout the city. The potential need for additional desalination units considering the optimization program in terms of capacity, availability of required utilities, land and production costs etc [1].

\subsubsection{Water conservation program}

- Implement a water conservation program aimed at reducing water consumption.

- Metering of all users, and pricing of water is already in effect, and applies to $100 \%$ of residential and commercial uses. This should be continued and enhanced where possible.

- Among the effective measures to be examined: Use native plants and landscaping requiring least amount of irrigation water; use irrigation techniques requiring least water. Maximize use of treated wastewater for irrigation instead of potable water. Public awareness campaign for water conservation at home, in public facilities, mosques, schools, recreational areas, hospitals and commercial facilities. Use appropriate modern plumbing fixtures helping to minimize water waste and losses and maximize water recycling.

\subsection{Potable water system}

Potable water is provided for domestic uses and firewater $\mathrm{m}$ the residential community and for the needs of operations staff in the industrial zones. Water produced at the desalination plant is disinfected and remineralized before distribution. Following this treatment, its quality complies with the World Health Organization's 1984 Guidelines for Drinking Water Quality.

All distribution piping is placed underground in utility corridors. The system is designed to maintain a minimum residual pressure of $3.5 \mathrm{~kg} / \mathrm{cm} 2$ at peak hour demand (Figure 4).

\subsubsection{Recommendations and policies}

- Explore new sources for potable water. Among the feasible options to be explored:

- Additional desalination units.

- SWCC as a potential source for additional water.

- Through design, minimize reliance on energy for distribution of water. For example:

- Use gravity flow wherever possible

- Encourage use of ground reservoirs feeding elevated tanks on top of buildings for efficient use of energy 


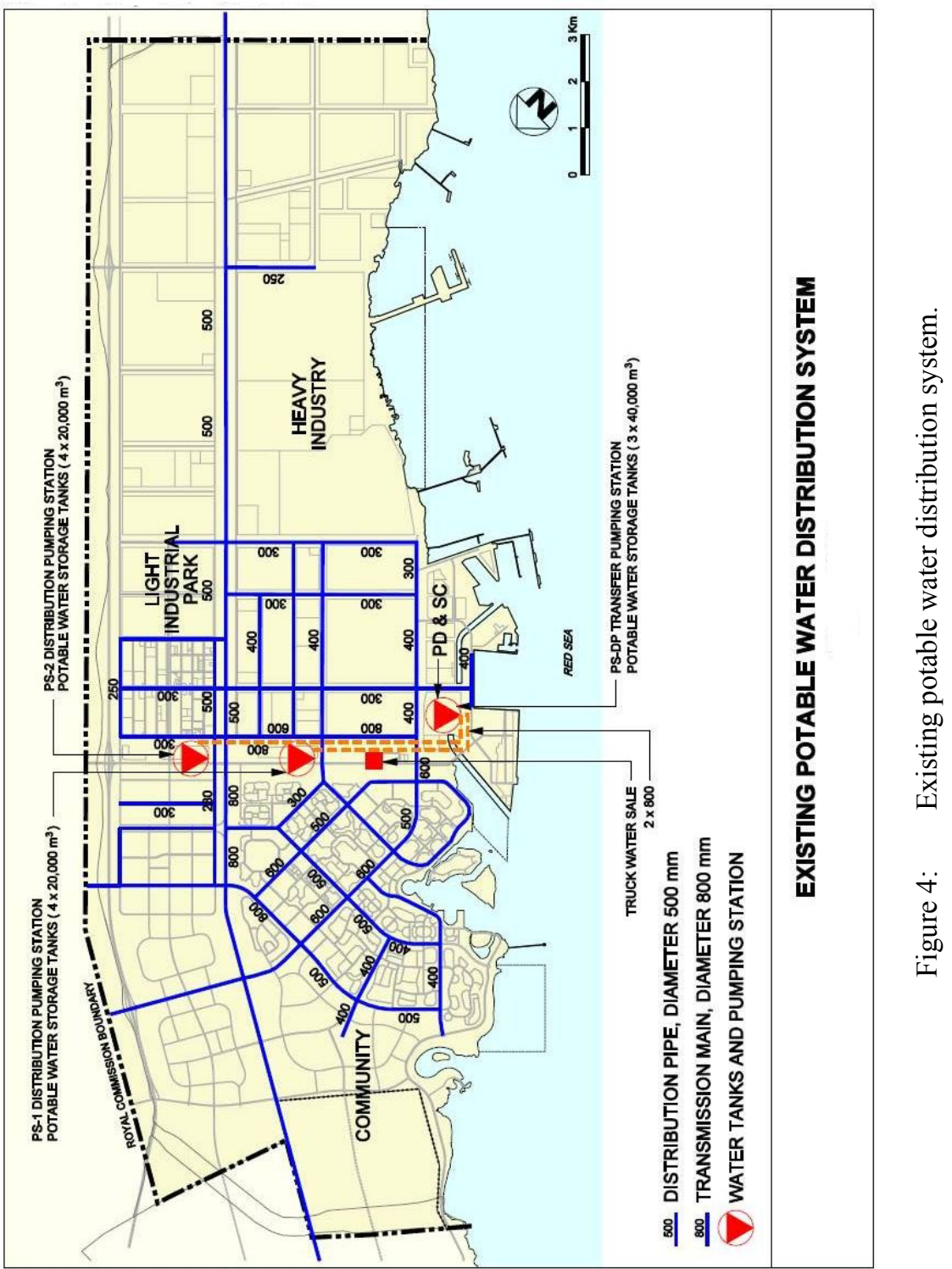




\subsubsection{Administrative elements}

- Coordinate with the Utilities Company, Marafiq, to guarantee water service to all users without discrimination or delay.

- Secure funding for installation, operation, and maintenance of facilities (charge customers for the expansion of facilities and operations) [1].

\subsection{Seawater cooling system}

The existing seawater supply system provides seawater to primary and secondary industries for cooling requirements, to the steam power plant for condenser and other auxiliary cooling, and to the desalination plant to produce desalinated water. The existing Seawater Pump House is located within the Power Plant site. Present seawater pumps are three $50,000 \mathrm{~m}^{3} / \mathrm{hr}$ and one $60,000 \mathrm{~m}^{3} / \mathrm{hr}$, and two $25,000 \mathrm{~m}^{3} / \mathrm{hr}$ pumps for the industrial manifold, and three $50,000 \mathrm{~m}^{3} / \mathrm{hr}$ and two $25,000 \mathrm{~m}^{3} / \mathrm{hr}$ pumps for the power and desalination manifold. The design head of these pumps is 20 meters, and they went into operation in 1983.

Provisions were made at the Seawater Pump House (SWPH) for future installation of three $50,000 \mathrm{~m}^{3} / \mathrm{hr}$ pumps on the industrial manifold and two $50,000 \mathrm{~m}^{3} / \mathrm{hr}$ pumps on the power and desalination manifold. However, it has been decided by the Royal Commission, based on seawater demand and hydraulic analysis (Figure 5), that future pump capacities should be $60,000 \mathrm{~m}^{3} / \mathrm{hr}$ instead of $50,000 \mathrm{~m}^{3} / \mathrm{hr}$. With the ultimate expansion of the SWPH, the ultimate pumping capacity of the SWPH is $700,000 \mathrm{~m}^{3} / \mathrm{hr}$ and the firm supply capacity is $580,000 \mathrm{~m}^{3} / \mathrm{hr}$. A new $60,000 \mathrm{~m}^{3} / \mathrm{hr}$ pump was installed on the industrial manifold and went into operation in year 2000 [1].

\subsubsection{Recommendations and policies: seawater cooling}

The main objectives for seawater cooling in this plan are:

- Continue current efforts for maximizing the capacity of the existing seawater cooling system, and encourage future industrial development in the southern sector to use/develop alternate cooling systems.

- Expansion plans should be prepared to meet future seawater cooling requirements with emphasis on the development of the southern sector.

- Encourage means for improving the reliability of the existing seawater pumping facility.

\subsection{Sanitary and industrial wastewater systems}

The sanitary wastewater system collects and treats sanitary wastewater produced by the community and industries at the Sanitary Wastewater Treatment Plant (SWTP). Industrial wastewater is collected and treated separately at the Industrial Wastewater Plant (IWTP).

The sanitary wastewater system collects and treats sanitary wastewater produced by the community and industries at the Sanitary Wastewater Treatment Plant (SWTP). Industrial wastewater is collected and treated separately at the Industrial Wastewater Plant (IWTP). Both plants are operated by the Royal Commission/Department of Water and Sanitary Sewage (Figure 6). 


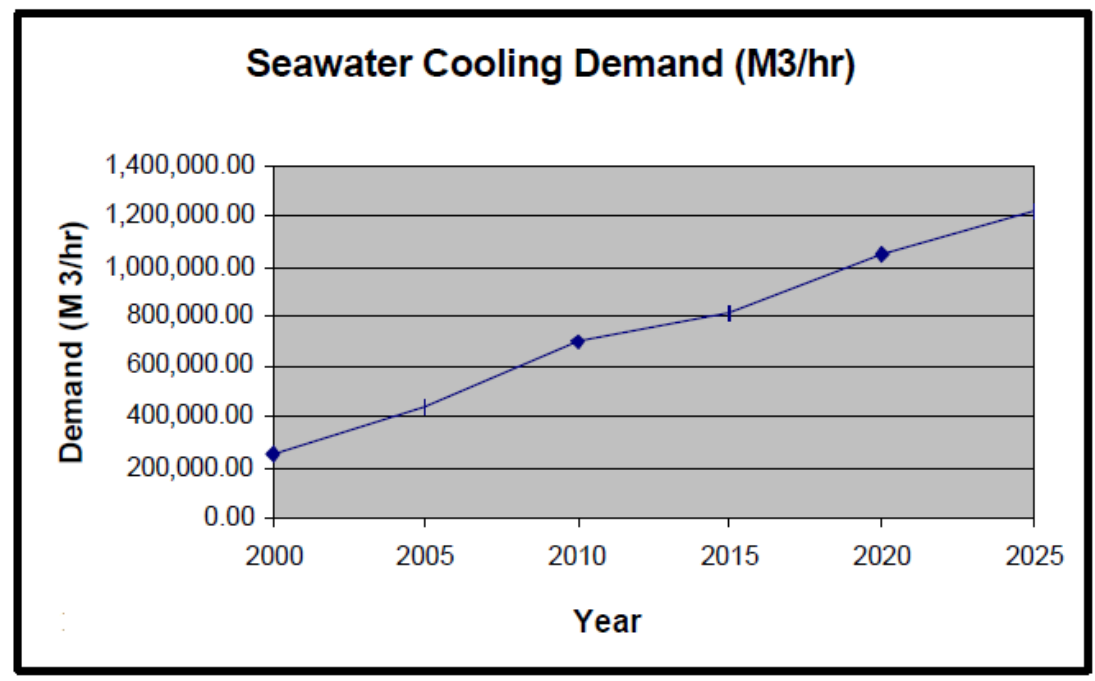

Figure 5: $\quad$ Seawater cooling demand.

Effluent from the treatment of sanitary wastewater, called Irrigation water or Treated Sewage Effluent (TSE) provides the main source of water for irrigation whereas effluent from industrial wastewater treatment called Reclaimed Water (RCW) is stored, and proposed to be used for industrial purposes such as cooling water and for fire fighting. Currently, however, reclaimed water is discharged to Red Sea [1].

\subsubsection{Sanitary wastewater system}

Sanitary wastewater is conveyed to the SWTP through an extensive collection system consisting of gravity sewers, lift stations, and force mains.

All pipes are placed underground within corridors along primary, secondary and tertiary roads. In total, there are $35 \mathrm{lift} /$ pump stations and $484 \mathrm{Km}$ of pipes varying in diameter from $110 \mathrm{~mm}$ to $1500 \mathrm{~mm}$. The primary wastewater collection system in the community can accommodate $57,000 \mathrm{~m}^{3}$ per day, which is equivalent to a population of approximately 170,000.

The prevailing flat topography and high groundwater level at YIC has called for a frequent use of lift stations to avoid excessive depths of the sewers. Force mains are used most extensively in the community area and in the Light Industrial Park. Areas of the community for which the collection system remains to be designed and all of the community expansion areas.

The average wastewater production for the community is approximately 400 liters per capita per day or a total of $20,000 \mathrm{~m}^{3} /$ day. This rate accounts for commercial uses and services. In the industrial area, the average production is approximately 90 liters per employee per day. 


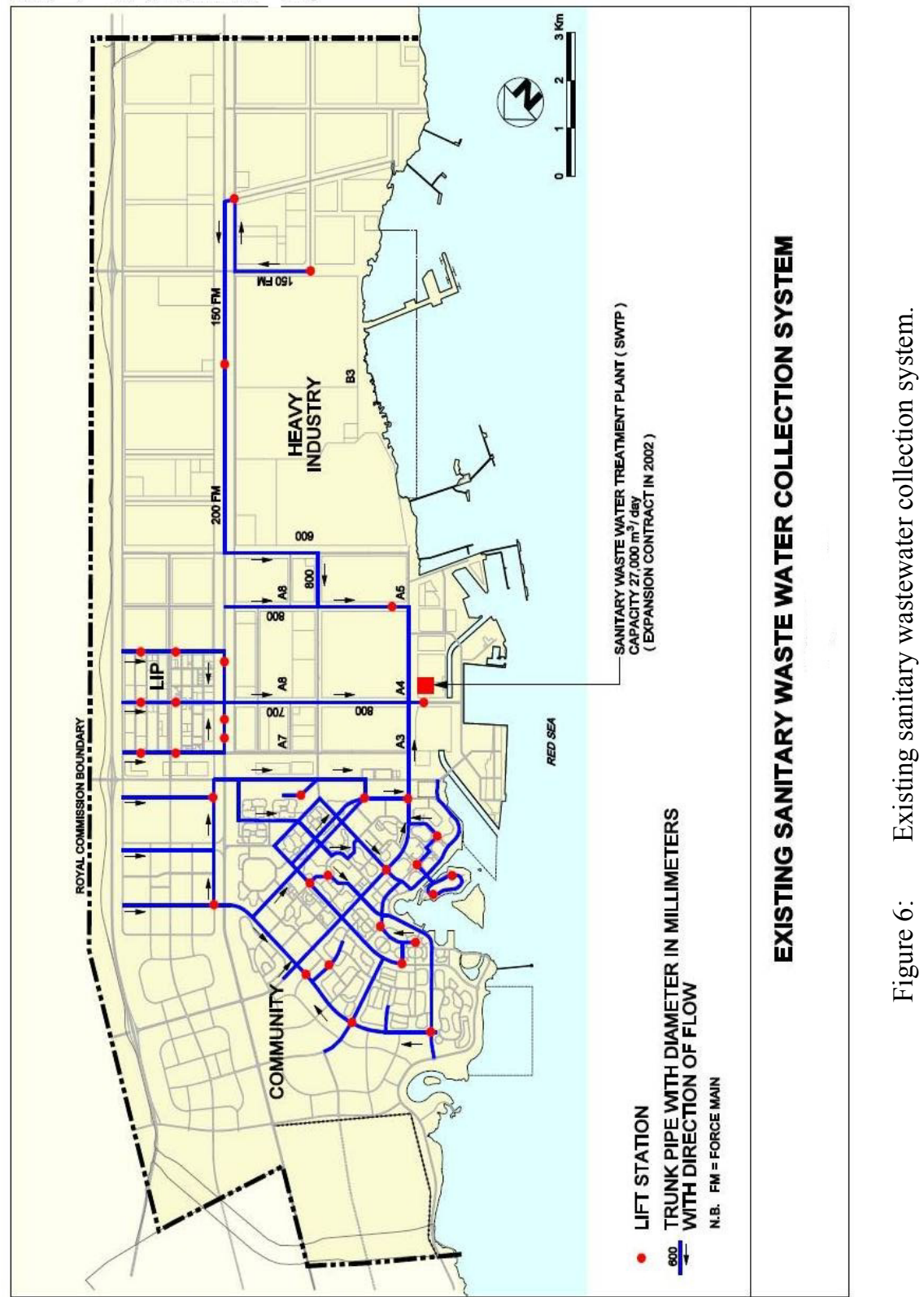


The Sanitary Wastewater Treatment Plant is located in the industrial zone adjacent to the Power Desalination and Seawater Cooling Plant inside the Treatment Plant Complex. The plant provides advanced secondary and tertiary treatment and chlorination. Sludge is dried on open drying beds. Grits is dewatered and transferred with dried sludge to the sanitary landfill. Wet sludge is used as feed for the compost plant.

The wastewater treatment provides an efficient and cost effective method for the production of a high quality effluent that is utilized a restricted water source for landscape irrigation only within the City. The irrigation network is $107 \mathrm{kms}$. with 4 storage tanks each with a capacity of $20,000 \mathrm{~m}^{3}$, and one pumping station, PSSP (Figure 7).

\begin{tabular}{|c|c|c|c|}
\hline \multicolumn{4}{|c|}{$\begin{array}{l}\text { WASTEWATER TREATMENT CAPACITY AND PRODUCTION } \\
\text { Table } 18-4\end{array}$} \\
\hline & $\begin{array}{c}\text { Current } \\
\text { Capacity } \\
\mathrm{m}^{3} / \text { day }\end{array}$ & $\begin{array}{c}\text { Current } \\
\text { Wastewater } \\
\text { Production } \\
\mathrm{m}^{3} / \text { day }\end{array}$ & $\begin{array}{c}\text { Estimated Future } \\
\text { Wastewater Production (at } \\
\text { Build-Out) } \\
\mathrm{m}^{3} / \text { day }\end{array}$ \\
\hline Sanitary WWTP & 27,000 & 20,000 & $60,000 \quad 80,000$ \\
\hline Industrial WWTP & 24,000 & 16,000 & $\begin{array}{ll}40,000 & 60,000 \\
\end{array}$ \\
\hline \multicolumn{4}{|c|}{$\begin{array}{l}\text { WWTP = Wastewater Treatment Plant } \\
\text { - The current sanitary WWTP is conceived for a total demand of } 54,000 \mathrm{~m}^{3} / \text { day } \\
\text { corresponding to a population of } 151,000 \text {. } \\
\text { - The design for the Industrial WWTP allows expansion in stages by adding units up to } \\
\text { an ultimate treatment capacity of } 90,000 \mathrm{~m}^{3} / \text { day. The original concept assumes one } \\
\text { plant for all industries including those of the Southem Sector. }\end{array}$} \\
\hline
\end{tabular}

Figure 7: Wastewater treatment capacity and production.

\subsubsection{Industrial wastewater system}

The industrial wastewater system consists of the collection system, lift stations and the industrial wastewater treatment plant (IWTP). The industrial wastewater collection system receives effluent from each industry that generates contaminated wastewater. Industrial Wastewater discharged into the system must conform to pretreatment standards. The industrial wastewater is then conveyed to a treatment plant by gravity and pressure pipelines, and 16 lift stations. The industrial wastewater collection pipes consists of 54 kilometers of pipes varying in diameter from 300 to $1000 \mathrm{~mm}$ and 16 industrial wastewater lift stations .

The IWTP is located at the wastewater treatment complex, adjacent to the sanitary wastewater treatment plant. The plant is designed to remove organic and inorganic pollutants from the wastewater to the extent that it can be reused by industry or discharged to the Red Sea without causing adverse environmental impact to the coastal marine water and the coral reef ecosystem. At present, reclaimed water is not used for irrigation purposes but offers a potential use in the future. 
The IWTP has the capacity to treat $24,000 \mathrm{~m}^{3} /$ day. The plant is designed with two trains each capable of treating $12,000 \mathrm{~m}^{3} /$ day and contains two oil and water separators. The Reclaimed water network system is $45 \mathrm{kms}$ in length and includes $24,000 \mathrm{~m}^{3}$ of storage at PSIP (2 tanks) and a pump station. At present, Industrial Wastewater amounts to $13,000 \mathrm{~m}^{3} /$ day [1].

\subsubsection{Recommendations and policies: wastewater treatment systems}

- Guarantee wastewater service to all users.

- Ensure through standard subdivision conditions of approval that any proposed development will have adequate sewer service, including assurance that both collection system and treatment capacity can be accommodated.

- Make the end user bear a fair share of wastewater collection system cost.

- $\quad$ Prepare/Update the Sewage Collection System Master Plan (within an

- integrated Water Resources Program for the city) covering the planning area.

- The current sanitary WWTP is conceived for a total demand of $54,000 \mathrm{~m}^{3} /$ day corresponding to a population of 151,000 .

- The design for the Industrial WWTP allows expansion in stages by adding units up to an ultimate treatment capacity of $90,000 \mathrm{~m}^{3} /$ day. The original concept assumes one plant for all industries including those of the Southern Sector.

- Develop and implement a "Zero Discharge Program" aiming at eliminating the effluent discharged from the treatment facilities to the Red Sea.

- Upgrade ponds to allow their use as additional treatment units.

- Encourage the use of reclaimed water for secondary water uses to the greatest extent feasible.

\subsection{Storm drainage}

The existing storm drainage system within the planning area is administered by the Royal Commission. Storm drain facilities include a flood control channel, open channels, underground drains, street gutters, natural drainage courses, basins, and culverts. Most drainage facilities are man-made but take advantage of natural channels and topography. The terrain of YIC and vicinity is generally flat and slopes slightly downward from the northeast to the coastline. The whole city is protected by a large flood channel, which intercepts rainstorm from areas outside Royal Commission boundaries. Therefore, the planning and design of storm drains in YIC may be restricted to subareas within the city boundaries. All drains in YIC discharge ultimately in the Red Sea.

The City's primary rainstorm drainage system consists of open channels, generally unlined with trapezoidal cross section. The secondary collectors receive rainstorm water from street pavement and discharge it into the primary collectors that are designed for a 50-year storm. Storm water is discharged from the network of primary collectors directly to the sea. 
The Royal Commission design criteria for storm drains are contained in the report: "RC General Design Criteria and Technical Guidelines" March 1989.

Within the city boundaries, there are four categories of drains may be identified according to their importance:

- Regional Drains: Regional drains are systems (Figure 8) using large channels and are of regional significance in that they accommodate flows originating outside the RC boundaries. The Flood Channel is the only regional channel is the planning area.

- Primary Drains: Primary drains are systems using $100 \mathrm{~cm}$ or more diameter pipes or equivalent channels and are of significance in that they provide additional capacity for flow originating outside the bounds of a District or a certain large development.

- For the Community Expansion Area and for future industry more primary drains need to be planned.

- Secondary Drains: Secondary drains are systems using conduits smaller than $100 \mathrm{~cm}$ diameter or equivalent but greater than $40 \mathrm{~cm}$ and serving the needs of a District, Residential Quarter or an isolated small drainage areas. Secondary drains connect eventually to primary drains or may discharge into natural channels or directly to the Sea. In this analysis, secondary drains are not identified.

- Local Drains: Local drains are systems using conduits smaller than 40$\mathrm{cm}$ in diameter or equivalent and serving the needs of a certain Residential Quarter or a small project. They eventually connect to secondary drains. Gutters and roadway pavement drains are examples of local drains [1].

\subsubsection{Recommendations and policies: storm drainage}

- Require a specific design for all storm drains for all residential subdivisions, and commercial, and industrial development in accordance with a Comprehensive Storm Drainage Plan. Design Primary and Secondary Storm drains within the planning area for a 25year flood. Street gutters will be designed for a 5- or 10-year flood, depending on their importance.

- Maximize use of underground or covered drain system in new development areas. Street flows may be carried within the curbed portion of the street. Storm water should not be carried in the street system more than 300 meters before interception with a drain.

\subsubsection{Detention basins}

Design detention basins for expansion area in line with current guidelines and provide a controlled rate of discharge not to disrupt the downstream peak loading from other such facilities. Hydrology calculations using the hydrograph method should be used to design the detention basins and for the sizing of related storm drains. 


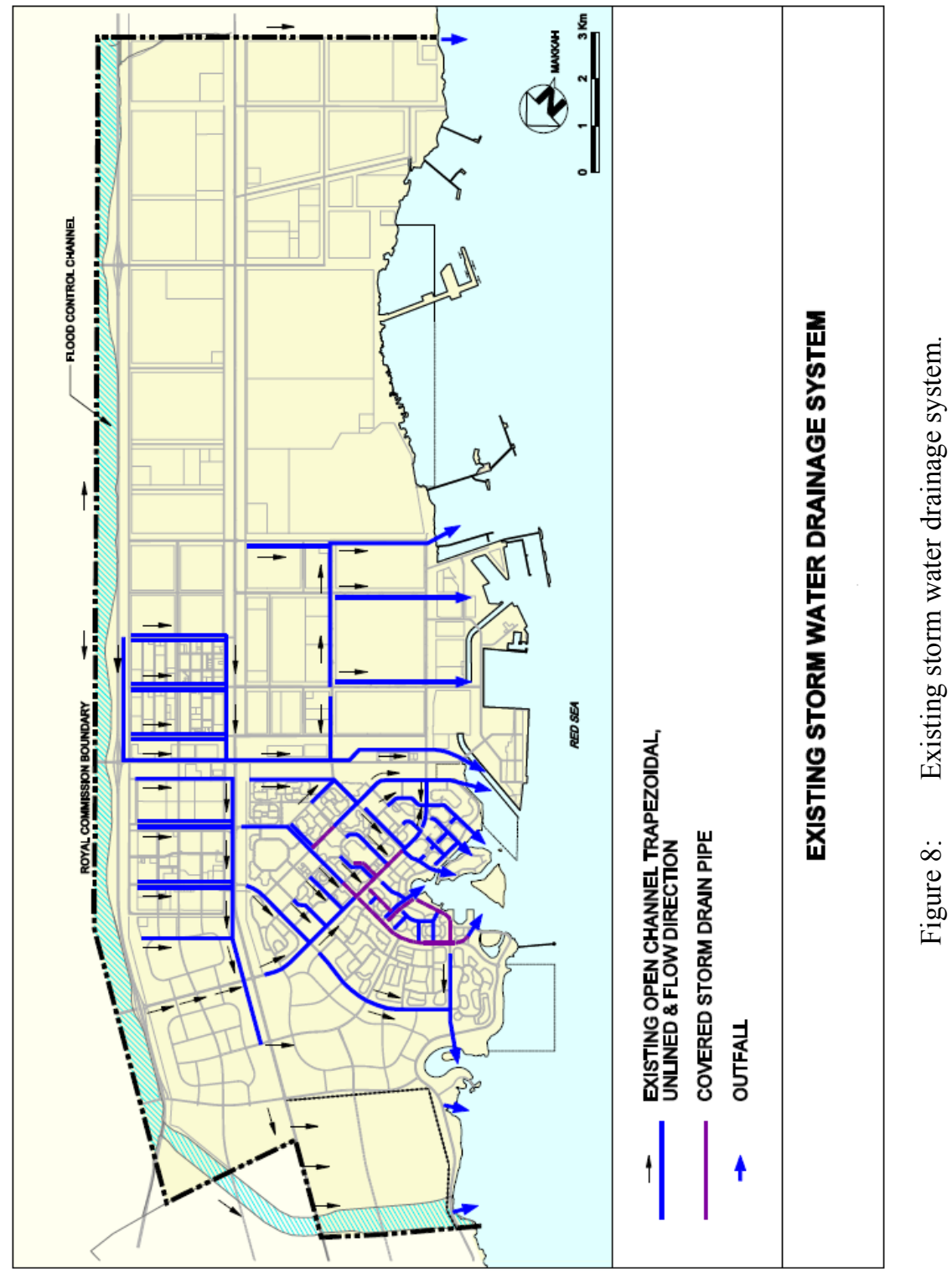




\subsection{The environmental programs- approach and planning}

The environmental programs at YIC are based on an "anticipation-prevention" approach and on international standards and regulations. While regulations governing environmental matters have been formulated to suit local conditions, they are occasionally more stringent than those in developed countries [1] (Figure 9).

\subsubsection{Water quality}

Local desalination plant produce freshwater for drinking, industrial processes, and firefighting, while the city's major industries use raw seawater to cool their process operations. A comprehensive monitoring program has been established to insure the quality of all types of water production and usage within the city.

\subsubsection{Seawater}

Seawater sampling has being going on at 18 stations at nearshore and offshore locations since 1983 . The analysis results constitute a unique baseline record of water quality, against which any future changes can be compared.

To prevent contamination of the Red Sea by the discharge of oily ballast water, YIC has built a ballast water treatment plant able to remove oil and grease down to $8 \mathrm{mg} / \mathrm{l}$.

Besides preserving the purity of Yanbu's water supply, the YIC's seawater monitoring program is aimed at protecting the offshore reef that parallels the coast near the industrial area. This coral reef serves as a storm barrier for the industrial port complex and is thus critical to the YIC's economy. Since corals are sensitive to changes in water temperature, it is imperative that seawater used for industrial cooling be returned to the Red Sea at a temperature that corals can tolerate.

\subsubsection{Marine ecology}

To minimize the impact of industrial development on marine flora and fauna at YIC, a comprehensive program exists to monitor local ecosystems.

As part of this program, several studies of the marine ecology of the YIC area have been conducted. The studies cover oceanography, coral reef ecology, nearshore and soft-bottom ecology, the mangroves, and shorebird populations and activities.

\subsubsection{Ground water}

A monitoring program has been established to observe any impact to the groundwater by industrial activities and to take appropriate remedial measures.

\subsubsection{Water quality and habitat protection}

Limit siltation generated by coastal development to within acceptable parameters, (e.g., dredge and fill, drainage discharges).

Conduct additional sea water circulation studies to address the potential effects of thermal discharges on the coastal environment. Determine the best 


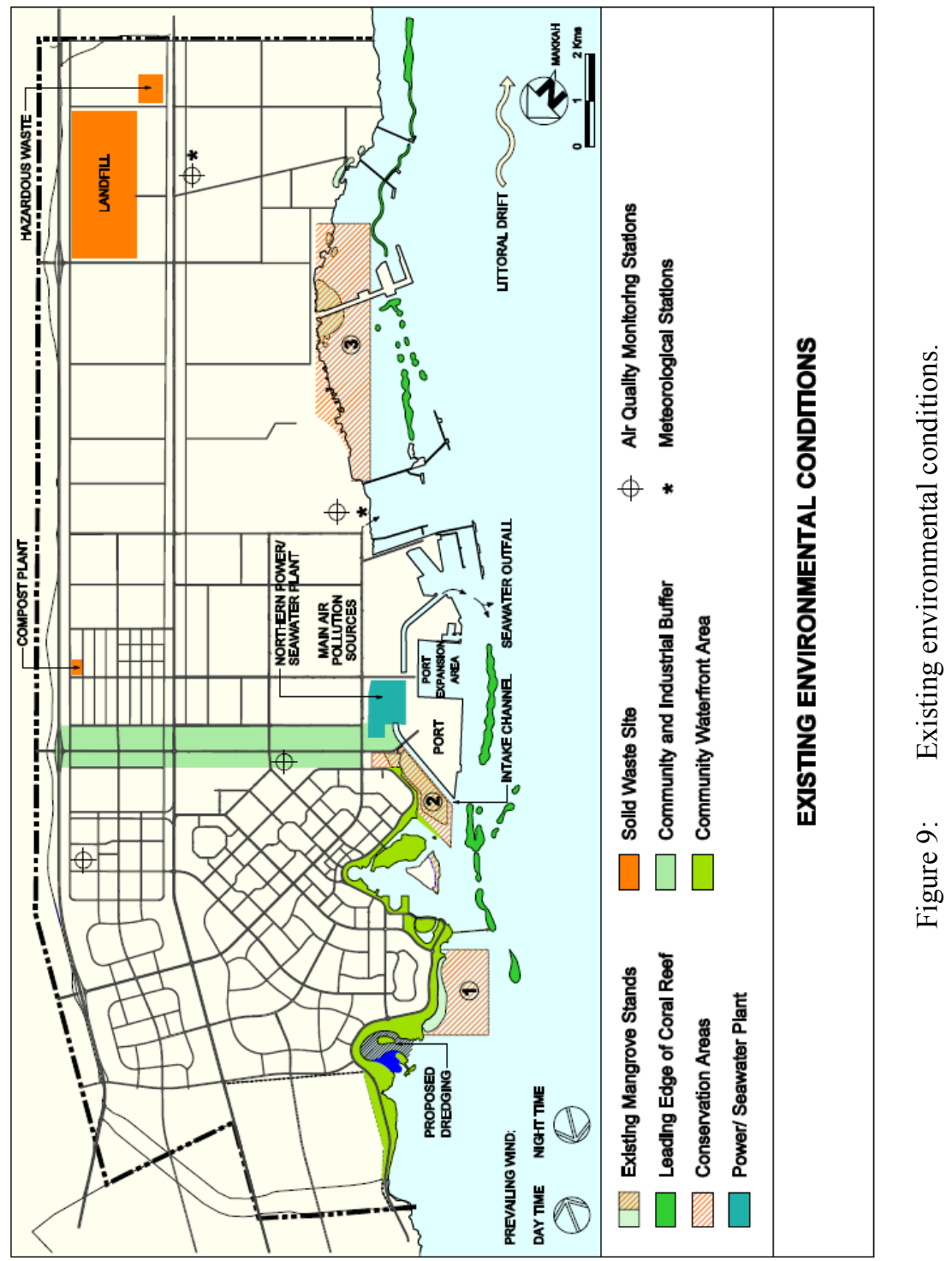


design for future outfall channels through the aid of thermal dispersion studies and seawater monitoring data, with the objective of protecting coral and sea grass habitat.

Monitor the health of the marine environment on an ongoing basis, including mangrove stands, coral reefs and sea grass habitat, to ensure that the condition of environmental health of the various elements remain within best standards.

Expand the scope of application for treated waters from both sanitary and industrial wastewater treatment plants.

Encourage industries to find ways to use reclaimed water in their process applications [1].

\section{YIC and sustainability}

The completion of the Master Plan policies has laid a solid foundation for the urban water sustainability. Approximately two-third of the city is dedicated to industrial development. At the northern end of the site upwind of the industrial area and separated from it by a buffer zone is the residential community. The entire residential area is to be ringed by a greenbelt. This green belt has many environmental and recreational activities such as coastal conservation areas, museum, parks and waterfront recreation. The greenways enhanced the quality of life through the provision of a healthy, safe energy-efficient transportation network, and provide linkages among the ascending hierarchy of recreation, commercial, public facilities, culminating finally with the city center and greenbelt.

The Royal Commission believes that industrialization and urban water sustainability are not mutually exclusive. By employing advanced technology as well as proven methods - industrialization, urban water sustainability, and the creation of safe, health residential areas have become a reality at YIC. Highly prized coral reef and mangrove swamp habitats have been preserved. Rigorous standards have been applied to protect human and environmental resources. The Consolidated Permit Program (CPP) governs all procedures associated with obtaining the certificates required to construct and operate an industrial facility in the city.

Other realizations regarding the sustainable management development is to modify the residential structure to give a broader range of housing types meeting the needs of all sectors of population and to encourage privatization and to allow major industrial companies participate in the housing development program which will benefit employees through Home Ownership Programs.

Finally, the approval of the City Development Plan (CDP) has laid solid foundation for the sustainable development of the city. The CDP translate various development Plans into a series of actions, and defines required lands uses/facilities in the community and industrial areas by year, location and use over the next 15 years. 


\section{References}

[1] Royal Commission for Jubail and Yanbu "Yanbu Al-Sinaiyah Master Plan Year 2000 “, December 2000. volume I pp. 7-12, volume II pp. 103, 383417, 429-441, 2000.

[2] Royal Commission for Jubail and Yanbu "Yanbu Industrial City, Facts \& Figures. pp. 1.1-1.3, 1996.

[3] Royal Commission for Jubail and Yanbu, "Quarterly Progress Report No. 219, July 2011, through 30 September 2011”. pp. 26. 